\title{
Efektivitas Hybrid Method (Metode TMa dan IK) pada Pembelajaran Daring untuk Mata Kuliah Statistik
}

\author{
Ani Mahrita ${ }^{1, *}$, Fahmi Aulia Rakhman ${ }^{2}$ and Meitiana ${ }^{3}$ \\ 1 Universitas Palangka Raya; animahrita@feb.upr.ac.id \\ 2 Kementerian ESDM; fahmiauliarakhman@gmail.com \\ 3 Universitas Palangka Raya; meitiana@feb.upr.ac.id \\ * Corres pondence a uthor: a nimahrita@feb.upr.ac.id; Tel.: +6281312432058
}

\begin{abstract}
The purpose of this study was to determine the effectiveness of the hybrid learning method (hybrid method) in economic and business statistics courses. The research method uses a mixed method between a quantitative approach and a qualitative approach using primary data. The data were tested using one of the different test analyzes, namely the Paired-Samples $T$ Test. The findings indicate that an effective hybrid method is used for classes of economic statistics and business. Students prefer to use the IK method combined with the TMa (virtual face) method because they can understand the material quickly and the method is very similar to conventional methods. The theoretical implication of this research is that the hybrid method is better used for online learning methods than the IK method. Meanwhile, the practical implication in this study is that teachers can use the hybrid method for mathematics-based and calculation-based courses because the results of the study show that computation-based statistics courses can be effectively implemented using the hybrid method.
\end{abstract}

Keywords: Covid-19; Hybrid Method; Collaboration Interpersonal Method (IK); Video Conference Method (TMa).

\begin{abstract}
Abstrak: Tujuan dari penelitian ini a dalah untuk mengeta hui efektivitas metode pembelajaran hybrid (hybrid method) pada mata kuliahstatistik ekonomi dan bisnis. Metode penelitian ini menggunakan mix method anta ra pendekatan kuantitatif dan pendekatan kualitatifmenggunakan data primer. Data diuji menggunakan salah satu a nalisis uji beda yaitu Paired-Samples T Test. Hasil temuan menunjukkan bahwa hybrid method seca ra signifikan efektif digunakan untuk mata kuliah s tatistik ekonomi da n bisnis. Mahasiswa lebih menyukai perkul iahan menggunakan metode IK yang dikombi nasi dengan metode TMa (tatap maya) karena dapat memahami materi dengan cepat dan metode tersebut sangat mi rip dengan metode konvensional. Implikasi teoretis dari penelitian ini a dalah hybrid method lebih baik digunakan untuk metode pembelajaran daring dibandingkan dengan metode IK. Sedangkan implikasi praktis da lam penelitian ini adalah pa ra pengajar dapat menggunakan hybrid method untuk ma ta kuliah yang berbasis matematika dan perhitungan karena hasil penelitian menunjukkan ba hwa untukmata kuliah statistikya ng berbasishitung-hitungan dapat secara efektif dilaksanakan dengan menggunakan hybrid method.
\end{abstract}

\section{PENDAHULUAN}

Virus Corona yang bermula dari Wuhan Cina pada Desember 2019 lalu hingga saat ini telah melanda beberapa negara termasuk Indonesia. Data terakhir sebaran Covid-19 di Indonesia tanggal 18 November 2020 sebanyak 479.720 yang terkonfirmasi positif, 402.347 dinyatakan sembuh, dan 15.503 dinyatakan meninggal (Covid-19, 2020). Pemerintah menetapkan beberapa aturan guna memutus rantai penyebaran Covid-19 yaitu dengan membatasi jarak interaksi antar masyarakat atau yang disebut dengan physical distancing dan juga kebijakan Work From Home (WFH) bagi para pekerja (Keputusan Menteri Kesehatan, 2020). Kebijakan lain dari Kementerian Pendidikan dan Kebudayaan dalam proses belajar mengajar yaitu kebijakan Belajar Dari Rumah (BDR) dimana proses belajar mengajar dapat dilakukan melalui dalam jaringan (daring) atau luar jaringan (luring) 
(Kemendikbud, 2020).

Pelaksanaan pembelajaran dari semua zona wajib dilakukan secara daring untuk mata kuliah teori. Sama halnya untuk mata kuliah praktik juga sebaiknya sedapat mungkin dilakukan secara daring (Dirjendikti, 2020). Hasil penelitian Aurora \& Effendi (2019) menunjukkan bahwa penggunaan media pembelajaran daring (e-learning) memiliki pengaruh positif terhadap motivasi belajar mahasiswa. Sejalan dengan penelitian Nadziroh (2017) yang menyatakan bahwa pembelajaran daring secara efektif dapat meningkatkan mutu pembelajaran, karena proses pembelajaran tidak hanya terpaku dalam satu waktu dan dalam ruangan saja. Permasalahan pada saat ini adalah terdapat banyak kendala dalam proses pembelajaran daring, salah satunya adalah penerapan metode pembelajaran yang efektif khususnya untuk Mata Kuliah Statistik Ekonomi dan Bisnis.

Mata kuliah Statistik Ekonomi dan Bisnis merupakan salah satu mata kuliah yang sulit dipahami oleh mahasiswa jika tidak dipraktikkan secara langsung karena bersifat sistematis, dan penuh dengan rumus-rumus yang membingungkan. Hal tersebut sejalan dengan penelitian Wahyuni dan Fuziah (2015) yang menyatakan bahwa nilai statistik atau aktivitas mahasiswa dalam mata kuliah statistik masih rendah sehingga dibutuhkan kajian lebih mendalam terkait metode pembelajaran yang efektif untuk mata kuliah tersebut. Mata kuliah Statistik Ekonomi dan Bisnis merupakan mata kuliah praktik namun masih dapat dilaksanakan secara daring, terlebih jika mahasiswa dalam kelas tersebut kapasitasnya lebih dari 20 orang. Metode pembelajaran daring yang dapat diterapkan adalah metode Interpersonal Kolaborasi (IK) dan metode Tatap Maya (TMa). Metode kegiatan belajar mengajar tersebut merupakan beberapa pilihan metode pembelajaran yang dapat diimplementasikan di kelas selama masa pandemi. Kebijakan tersebut dikeluarkan oleh Pimpinan di Universitas Palangka Raya berdasarkan Surat Edaran Rektor Universitas Palangka Raya tentang penyelenggaraan kegiatan akademik dalam tatanan new normal (Rektor, 2020). Metode IK adalah metode pembelajaran yang dilakukan melalui forum diksusi online berupa Whatsapp Group, email atau LMS yang sudah tersedia seperti aplikasi Classroom, Edmodo, Quipper, Moodle, dll. Metode TMa adalah metode pembelajaran yang hanya dilakukan melalui tatap maya atau tatap muka secara daring dengan menggunakan aplikasi Zoom, Google Meet, Webex, atau aplikasi video conference lainnya. Lebih lanjut, metode yang dilakukan dalam penelitian ini adalah Hybrid Method yaitu campuran antara metode Interpersonal Kolaborasi (IK) dan metode Tatap Maya (TMa). Aplikasi yang digunakan dalam metode IK pada penelitian ini adalah aplikasi Edmodo dimana menurut Cakrawati (2017) menyatakan bahwa penggunaan edmodo dalam proses belajar mengajar lebih efektif dan efisien dalam segi waktu. Sejalan dengan pernyataan Kongchan (2012) yang mengungkapkan bahwa para pengajar di Thailand menganggap Edmodo sebagai aplikasi pembelajaran yang wonderful and user-friendly sehingga memungkinkan mereka sebagai pengajar yang non-digital-native dapat menjalankan kelas daring dengan baik. Aplikasi Edmodo juga dianggap sebagai sarana pembelajaran tambahan yang bermanfaat karena dapat meningkatkan motivasi dan partisipasi siswa dalam kegiatan pembelajaran daring (Manowong, 2016). Lebih lanjut, aplikasi yang digunakan dalam metode TMa pada penelitian ini adalah aplikasi Google Meet. Pilihan tersebut berdasarkan kesepakatan yang dilakukan bersama para mahasiswa atau partisipan dalam penelitian ini karena aplikasi tersebut dianggap lebih ringan dan user-friendly dibandingkan aplikasi lain seperti Zoom atau Webex terutama bagi mahasiswa yang ada di daerah-daerah terpencil.

Penelitan ini bertujuan untuk menguji efektivitas metode pembelajaran daring pada mata kuliah Statistik Ekonomi dan Bisnis dengan melihat perbedaan nilai mahasiswa sebelum dan sesudah menggunakan Hybrid Method. Sebelum menggunakan Hybrid Method, metode yang digunakan adalah metode IK.

\section{METODE}

Penelitian ini menggunakan mix method yaitu pendekatan kuantitatif dan kualitatif dalam menjelaskan suatu fenomena atau masalah. Pendekatan kuantitatif bertujuan untuk melihat efektivitas metode pembelajaran daring sebelum dan sesudah menggunakan hybrid method melalui 
jawaban kuis. Sedangkan pendekatan kualitatif bertujuan untuk melihat tanggapan atau penilaian mahasiswa terhadap kedua metode pembelajaran daring tersebut (IK dan hybrid method) melalui kuesioner yang disebarkan setelah kedua metode diimplementasikan.

Sumber data diperoleh melalui data primer yaitu pemberian kuis dan kuesioner/angket. Pemberian kuis dilaksanakan pada setiap akhir pertemuan setelah materi disa mpaikan menggunakan masing-masing metode yang berbeda yaitu metode IK dan metode Hybrid. Pemberian kuesioner diberikan setelah semua metode dilaksanakan untuk mengetahui tanggapan atau penilaian mahasiswa terkait kedua metode tersebut.

Pada metode IK, dosen atau tenaga pendidik memposting materi dan video rekaman ${ }^{1}$ ke Edmodo, kemudian dilakukan sesi diskusi atau tanya jawab melalui fitur komentar dilanjutkan dengan mengerjakan kuis pada akhir pertemuan yang masih dilaksanakan melalui aplikasi Edmodo. Hasil kuis pada metode IK ini digunakan sebagai data pretest atau data sebelum menggunakan Hybrid Method.

Pada Hybrid Method, perkuliahan dilaksanakan secara Tatap Maya (TMa) di mana dosen atau tenaga pendidik menyampaikan materi melalui Google Meet yang dilanjutkan dengan sesi diskusi atau tanya jawab. Pada akhir pertemuan, diadakan kuis melalui aplikasi Edmodo. Hasil kuis menggunakan Hybrid Method ini digunakan sebagai data posttest atau data sesudah menggunakan Hybrid Method.

Sampel dalam penelitian ini adalah seluruh mahasiswa dari salah satu kelas Statistik Ekonomi dan Bisnis pada Fakultas Ekonomi dan Bisnis Universitas Palangka Raya (kelas C), sebanyak 52 orang. Hasil kuis sebelum dan sesudah menggunakan Hybrid Method tersebut disusun kemudian diolah menggunakan metode uji beda Paired-Samples T Test. Menurut Widiyanto (2013).Paired-Samples T Test digunakan untuk mengkaji keefektifan sebuah perlakuan (treatment) yang ditandai dengan adanya perbedaan rata-rata sebelum dan rata-rata sesudah diberikan perlakuan. Perlakuan dalam penelitian ini adalah penggunaan Hybrid Method (data terlampir).

Data selanjutnya diolah menggunakan metode Paired-Samples T Test, kemudian dianalisis untuk mengetahui apakah terdapat perbedaan hasil pembelajaran yang signifikan terhadap penerapan Hybrid Method untuk mata kuliah Statistik Ekonomi dan Bisnis.

Kriteria pengujian sebagai dasar pengambilan keputusan pada metode ini adalah jika probabilitas (Asymp.Sig) $<0,05$ maka terdapat perbedaan yang signifikan dari hasil pembelajaran mahasiswa sebelum dan sesudah menggunakan Hybrid Method. Sebaliknya, jika probabilitas (Asymp.Sig) > 0,05 maka tidakterdapat perbedaan yang signifikan dari hasil pembelajaran mahasiswa pada kelas Statistik Ekonomi dan Bisnis sebelum dan sesudah menggunakan Hybrid Method.

\section{HASIL DAN PEMBAHASAN}

Hasil

Berdasarkan hasil uji Paired-Samples $T$ Test, ditemukan bahwa terdapat perbedaan hasil pembelajaran mahasiswa yang signifikan antara sebelum dan sesudah menggunakan Hybrid Method. Hal tersebut dapat dilihat dari tingkat signifikansi pada hasil pengujian yang berada pada level $1 \%$ $(0,01)$. Hasil pengujian tersebut dapat dilihat pada tabel di bawah ini.

Tabel 1. Hasil Uji Paired-Samples T Test

\begin{tabular}{c|c|c}
\hline & Pretest & Posttest \\
\hline Jumlah sampel & 52 & 52 \\
\hline Mean & 50.96 & 69.61 \\
\hline Mean Pretest - Posttest & \multicolumn{2}{|c}{18.65} \\
\hline t-hitung & \multicolumn{2}{|c}{-5.889} \\
\hline
\end{tabular}

\footnotetext{
${ }^{1}$ Peneliti menggunakan aplikasi OBS Portable untuk merekam video penjelasan materi yang dikirimkan ke Edmodo.
} 


\begin{tabular}{c|c}
\hline Sig. & 0.000 \\
\hline
\end{tabular}

Dari hasil uji beda di atas dapat dilihat bahwa rata-rata nilai mahasiswa pada saat menggunakan metode IK atau sebelum menggunakan hybrid method adalah sebesar 50.96 . Setelah menggunakan hybrid method meningkat menjadi 69.61 poin. Rata-rata selisih nilai dari pretest (sebelum) dan posttest (sesudah) adalah sebesar 18.65 poin dengan t-hitung senilai -5.889 dan tingkat signifikansi sebesar 0.000 atau kurang dari (<) 0.01 yang mengindikasikan bahwa uji beda tersebut signifikan di level $1 \%$.

Tanggapan mahasiswa terkait pelaksanaan kedua metode tersebut dapat dilihat dari hasil jawaban kuesioner sebagai berikut:

Tabel 2. Tanggapan Pelaksanaan Metode Pembelajaran IK

\begin{tabular}{|c|c|}
\hline No. & Tanggapan \\
\hline 1. & Mudah dimengerti \\
\hline 2. & Karena ini yang paling mudah dan materi yang diberikan bisa cepat dipahami \\
\hline 3. & Sangat mamahami siswa \\
\hline 4. & Karena a pabila lupa atau masih belum paham dapat di putar kembali dan di baca kembali \\
\hline 5. & $\begin{array}{l}\text { Karna untuk saya pribadi saya lebih mudah paham dengan pembelajaran menggukan } \\
\text { metode IK }\end{array}$ \\
\hline 6. & $\begin{array}{l}\text { Karna metode ini mudah dipahami jika di sertakan dengan rekaman vidio dan rekaman } \\
\text { Vidionya dapat di ulang-ulang kembali. Terima kasih }\end{array}$ \\
\hline 7. & $\begin{array}{l}\text { Pada metode IK saya dapat mempelajari dari ppt dan dapat mengulang kembali video } \\
\text { yang di berikan saat ada yg kurang paham. jika ada beberapa materi yg memng sulit } \\
\text { dimengerti dapat berdiskusi di edmodo }\end{array}$ \\
\hline 8. & $\begin{array}{l}\text { Alasan saya memilih metode IK karena menurut saya, saya lebih mudah memahami dan } \\
\text { mengikuti setiap alur penjelasan yang ibu sampaikan. }\end{array}$ \\
\hline 9. & Karena, vidio dapat diputar ulang jika kurang paham \\
\hline 10. & $\begin{array}{l}\text { Lebih mudah dan efektif khususnya memahami materi karena dijelaskan langsung cara } \\
\text { caranya misalnya dalam pengerjaan contoh contoh soal tiap materi. }\end{array}$ \\
\hline 11. & $\begin{array}{l}\text { Karena metode pembelajaran ini akan sangat mempermudah mahasiswa untuk } \\
\text { memahami materi terkait materi pembelajaran yg diberikan }\end{array}$ \\
\hline 12. & $\begin{array}{l}\text { Ketika dengan menggunakan metode video, saya dengan mudah bisa mengulang-ngulang } \\
\text { video terkait materi yang belum bisa saya pahami. }\end{array}$ \\
\hline 13. & $\begin{array}{l}\text { Metode pembelajaran IK lebih efektif karena dalam bentuk video mahasiswa dapat } \\
\text { mengulang ulang video tersebut }\end{array}$ \\
\hline 14. & $\begin{array}{l}\text { Karena dengan membaca materi serta mendengarkan rekaman penjelasan berulangkali } \\
\text { bisa membuat saya lebih mudah mengerti terutama di contoh soal }\end{array}$ \\
\hline 15. & Karena lumaian paham dengan mengunakan metode ini \\
\hline 16. & Karena saya bisa mengulang rekaman video penjelasan dosen jika saya tidak mengerti \\
\hline 17. & Karena dalam metode pembelajaran IK kita sudah menerapkannya \\
\hline 18. & karena melalui metode pembelajaran IK menurut saya sudah nyaman \\
\hline 19. & $\begin{array}{l}\text { Pemberian video di edmodoo, dan diskusi di kolom komentar lebih saya sukai. Tidak } \\
\text { terkendala jaringan, dan lebih mudah dilakukan. Kalau yang google meet, kadang kalau } \\
\text { telat beresiko karena kendala jaringan, akan ketinggalan materi. Mengingat tidak semua } \\
\text { mahasiswa ada di kota. }\end{array}$ \\
\hline 20. & karna lebih mudah di ulang materi pptnya \\
\hline 21. & $\begin{array}{l}\text { Karena secara keseluruhan metode pembelajaran tersebut sudah dapat dilaksanakan } \\
\text { dengan baik }\end{array}$ \\
\hline
\end{tabular}




\begin{tabular}{c|l}
\hline 22. & $\begin{array}{l}\text { Karena saya bisa mengulang ulang vidio nya kalau saya belum paham, dan penjelasan } \\
\text { dari bu dosen sangat bagus }\end{array}$ \\
\hline 23. & Karena jika belum mengerti bisa dilihat kembali dan mengulangi video pembelajaran nya \\
\hline 24. & $\begin{array}{l}\text { selain materi menggunakkan ppt, video penjelasan dari dosen juga penting menurut } \\
\text { saya, karena tidak setiap individu langsung paham dengan hanya di berikan ppt } \\
\text { penjelasan berupa video sangat membantu untuk memahami materi yang di berikan. } \\
\text { selain itu juga kita dapat mengakses setiap saat. }\end{array}$ \\
\hline 25. & $\begin{array}{l}\text { Menurut saya, metode ini lebih efektif dalam penggunaan waktu, kuota dan mudah } \\
\text { untuk memahami materi, karena video ppt tersebut bisa di putar berulang-ulang. }\end{array}$ \\
\hline 26. & $\begin{array}{l}\text { Saya sangat setuju dengan metode IK, karna saya lebih memahaminya dan apabila kurang } \\
\text { mengerti atas materinya, bisa mengulang lagi rekaman video secara terus menerus } \\
\text { sampai mengerti. Dan hal itu mempemudah saya untuk lebih memahami materi. }\end{array}$ \\
\hline 27. & $\begin{array}{l}\text { Karena ketika saya tidak paham isi materi, saya dapat memutar ulang Vidio secara } \\
\text { berulang-ulang sampai bisa memahami isi materi tersebut. }\end{array}$ \\
\hline 28. & $\begin{array}{l}\text { Karena efisien waktu dan biaya, selain itu materi dpt diputar kembali dgn visual dan } \\
\text { audio yang mendukung sehingga dpt lebih memahami }\end{array}$ \\
\hline
\end{tabular}

Setelah metode IK dan hybrid method di implementasikan. Mahasiswa diminta memberikan tanggapan melalui kuesioner untuk mengetahui metode mana yang lebih disukai pada pembelajaran mata kuliah statistik. Tanggapan untuk metode IK dapat dilihat pada Tabel 3 di atas bahwa dari 28 tanggapan yang diberikan oleh mahasiswa sebagian besar menyukai metode IK karena menyukai metode yang digunakan yaitu pemberian materi yang dijelaskan oleh dosen pengampu mata kuliah dalam sebuah video dan dikirimkan pada aplikasi edmodo. Pemberian materi melalui video dianggap lebih mudah dipahami untuk mata kuliah statistik karena dapat dilihat berulang-ulang sampai benarbenar mengerti. Selain itu, $62.8 \%$ mahasiswa lebih menyukai metode pembelajaran IK dibandingkan metode pembelajaran hybrid yang hanya $34.9 \%$.

Tabel 3. Tanggapan Pelaksanaan Pembelajaran Hybrid Method

\begin{tabular}{c|l}
\hline No. & \multicolumn{1}{|c}{ Tanggapan } \\
\hline 1. & Karna biar lebih jelas dan bisa lebih memahami \\
\hline 2. & $\begin{array}{l}\text { Karena memahami sesuatu tidak mudah hanya dengan membaca namun harus disertai } \\
\text { dengan tatap muka langsung agar kita tau bagian mana yang memang harus diperjelas } \\
\text { pemahamannya dan juga bisa cepat tanggap jika adanya Latihan-Latihan karena praktek } \\
\text { langsung lebih mudah dipahami dari pada teori }\end{array}$ \\
\hline 3. & $\begin{array}{l}\text { Lebih bisa memahami karena setelah pemberian materi kemudian langsung di jelaskan } \\
\text { secara langsung }\end{array}$ \\
\hline 4. & $\begin{array}{l}\text { Saya milih hybrid method karna metode inilah menurut saya yang paling mudah, dan } \\
\text { paham dalam memahami materi }\end{array}$ \\
\hline 5. & $\begin{array}{l}\text { Karena habis diberi bahan ppt kita harus dijelaskan bagaimana cara mengerjakan nya dan } \\
\text { supaya mahasiswa sampai paham sekali }\end{array}$ \\
\hline 6. & $\begin{array}{l}\text { Karena dosen secara langsung menjelaskan, dan langsung membahas materi dari pada } \\
\text { memberi file pdf tapi tidak dapat di pahami }\end{array}$ \\
\hline 7. & Mudah memahami materi yang diberikan dosen \\
\hline 8. & Memudahkan mahasiswa dalam memahami materi yang di berikan \\
\hline 9. & Karena melalui google meet itu memudahkan kita diskusi meskipun tidak tatap muka \\
\hline 10. & Karena lebih dapat memahami karena dijelaskan secara langsung \\
\hline 11. & Karena mudah di pahami dan di mengerti \\
\hline 12. & saya bisa lebih memahami dgn metode ini \\
\hline 13. & Karena dari kedua metode itu, metode inilah yang paling mudah untuk kita mengerti \\
\hline
\end{tabular}




\begin{tabular}{c|l}
\hline No. & \multicolumn{1}{c}{ Tanggapan } \\
\hline & $\begin{array}{l}\text { materi yang disampaikan, karena disitu bukan hanya materi yang berikan tetapi juga ada } \\
\text { penjelasan dari dosennya. }\end{array}$ \\
\hline 14. & $\begin{array}{l}\text { menurut saya dari semua pembelajaran daring/online melalui media apapun kurang } \\
\text { untuk di rekomendasi kan,karna sulit untuk di mengerti dan ilmu yg di dapatkan pun } \\
\text { sedikit,tapi dari kedua pilihan tersebut yg mungkin bisa untuk di gunakan sementara ini } \\
\text { atau yg lebih mudahnya melalui google meet/zoom }\end{array}$ \\
\hline 15. & Karna lebih memudahkan seperti kuliah normal tatap muka \\
\hline
\end{tabular}

Pada Tabel 4. di atas dapat dilihat tanggapan mahasiswa terkait metode pembelajaran hybrid atau hybrid method. Secara garis besar mahasiswa menyukai hybrid method untuk mata kuliah statistik adalah karena penjelasan yang diberikan melalui tatap maya dapat lebih cepat dipahami karna dapat bertanya secara langsung dan hampir sama dengan metode pembelajaran konvensional.

\section{Pembahasan}

Hartanto (2016) mengungkapkan bahwa teknologi komunikasi dan informasi yang mudah dan murah akan menghilangkan batasan ruang dan waktu yang selama ini membatasi dunia pendidikan. Salah satunya adalah pembelajaran daring. Pembelajaran daring dapat memudahkan mahasiswa untuk bisa mengakses materi dimanapun dan kapanpun tanpa batasan ruang dan waktu. Kemudahan-kemudahan yang diberikan pembelajaran daring tersebut juga didukung oleh metode yang dianggap efektif dalam proses pembelajaran. Hasil penelitian ini menunjukkan bahwa metode hybrid merupakan metode yang efektif yang dapat digunakan untuk mata kuliah statistik ekonomi dan bisnis. Metode hybrid dapat memudahkan mahasiswa untuk memahami materi dan meningkatkan nilai statistik.

Keefektifan hybrid method diukur melalui analisis uji beda atau pengujian perbedaan nilai dari hasil evaluasi yang terbukti signifikan. Menurut Dimiyati dan Mujiono (1999) evaluasi dilakukan untuk mengetahui tingkat pemahaman mahasiswa dalam mencapai tujuan pembelajaran. Salah satu indikator atau alat ukur pemahaman mahasiswa dalam evaluasi adalah nilai tes/kuis. Berdasarkan hasil kuis pada Tabel 2. menunjukkan bahwa hybrid method yaitu "pemberian materi berupa file ppt di Edmodo, dilanjutkan dengan penjelasan dan diskusi secara langsung melalui video conference (google meet)" merupakan metode yang paling efektif dan terbukti signifikan setelah di uji menggunakan metode Paired-Samples $T$ Test. Metode ini juga dianggap efektif karena nilai mahasiswa lebih tinggi menggunakan hybrid method dibandingkan dengan menggunakan metode IK. Di sisi lain, berdasarkan hasil survei terkait pelaksanaan kedua metode tersebut yang dilihat melalui tanggapan mahasiswa justru memberikan hasil sebaliknya. Mahasiswa lebih menyukai metode IK dibandingkan metode hybrid, karena materi dianggap lebih mudah dipahami melalui video penjelasan yang di unggah di aplikasi edmodo. Mayoritas mahasiswa baranggapan bahwa dengan adanya rekaman video dari metode IK memudahkan mereka untuk mengulang kembali rekaman materi sampai berkali-kali hingga benar-benar paham.

Hasil survei tersebut menunjukkan bahwa metode IK memang lebih disukai namun kurang membantu mahasiswa dalam memahami materi perkuliahan secara efektif dan efisien. Pada hybrid method nilai rata-rata kuis mahasiswa lebih tinggi dikarenakan mahasiswa lebih cepat memahami materi pada saat materi dijelaskan secara tatap maya. Seperti tanggapan-tanggapan yang dikemukakan oleh mahasiswa pada Tabel 3 dan 4, mayoritas menyatakan bahwa mereka lebih menyukai hybrid method karena hampir sama seperti pembelajaran konvensional sehingga lebih mudah dipahami. Apa yang tidak dimengerti dapat langsung ditanyakan sehingga materi dapat langsung dipahami pada saat itu juga. Hal ini juga memengaruhi hasil kuis yang mereka kerjakan setelah pemberian materi disampaikan. Sejalan dengan penelitian Mustakim (2020) yang menyatakan bahwa kualitas pembelajaran untuk pelajaran hitung-hitungan dianggap lebih mudah 
dipahami jika dilakukan melalui video call atau video conference. Hal tersebut juga mendukung penelitian Suartini (2020) yang menyatakan bahwa mayoritas mahasiswa memang memilih/menginginkan pembelajaran tatap muka secara langsung (konvensional). Dengan demikian, dalam penelitian ini metode pembelajaran tatap maya pada hybrid method terbukti lebih efektif dilaksanakan karena hampir sama dengan metode konvensional.

\section{KESIMPULAN}

Anjuran pemerintah untuk melaksanakan WFH selama masa pandemi covid-19 juga terus dilaksanakan oleh semua pihak, tidak terkecuali dunia pendidikan. Dalam dunia pendidikan semua kegiatan pembelajaran dapat dilakukan melalui daring. Metode pembelajaran daring sangat memengaruhi efektivitas pembelajaran daring selama masa pandemi covid-19. Beberapa mata kuliah kemungkinan memiliki metode yang berbeda dalam pelaksanaan pembelajaran agar dapat berjalan dengan efektif dan efisien. Dalam konteks ini, peneliti berfokus kepada efektivitas metode pembelajaran untuk mata kuliah statistik ekonomi dan bisnis. Metode yang ditawarkan adalan metode IK dan hybrid method (kombinasi antara IK dan TMa). Berdasarkan hasil penelitian menggunakan 52 sampel mahasiwa kelas statistik ditemukan bahwa hybrid method merupakan metode yang terbukti efektif untuk mata kuliah statistik ekonomi dan bisnis.

Hybrid method dianggap efektif berdasarkan hasil analisis uji beda menggunakan metode PairedSamples T Test yang terbukti signifikan di level 1\%. Meskipun pengujian nilai kuis menunjukkan hasil yang signifikan, namun hasil survei menunjukkan kesimpulan yang berbeda. Hasil survei menunjukkan mahasiswa lebih menyukai metode IK dibandingkan hybrid method.

Temuan tersebut mengindikasikan bahwa mahasiswa lebih menyukai materi yang disampaikan melalui rekaman video dibandingkan dengan penjelasan melalui tatap maya. Namun demikian, metode tersebut tidak efektif dan efisien jika membutuhkan evaluasi hasil pembelajaran secara langsung. Implementasi Hybrid method dapat dikatakan lebih efektif karena dapat memberikan pemahaman kepada mahasiswa secara langsung dan cepat, karena jika tidak mengerti dapat ditanyakan secara langsung kepada dosen saat tatap maya. Berbeda halnya dengan metode IK, durasi mahasiswa dalam memahami materi lebih lama karena menganggap materi dapat diakses kapan saja dan dapat ditonton berulang-ulang melalui video sehingga waktu memahami materi cenderung lebih lama dan hal tersebut berpengaruh terhadap hasil evaluasi atau pengisian kuis.

Hasil penelitian ini memberikan implikasi teoritis dan praktis. Implikasi teoritis pada penelitian ini terkait metode pembelajaran yang dapat digunakan selama masa pandemi covid-19 yakni menggunakan metode hybrid method karena rata-rata nilai pada metode hybrid method lebih tinggi dibandingan dengan metode IK. Implikasi praktis pada penelitian ini terkait pilihan mata kuliah dalam menerapkan hybrid method. Para dosen dapat menerapkan hybrid method dalam proses belajar mengajar untuk mata kuliah praktik berbasis matematika atau perhitungan karena hasil penelitian ini menunjukkan bahwa untuk mata kuliah statistik yang berbasis hitung-hitungan dapat secara efektif dilaksanakan dengan menggunakan hybrid method.

Terdapat beberapa keterbatasan dalam penelitian ini yakni: (1) hasil evaluasi yang hanya dilaksanakan satu kali untuk setiap metode sehingga rata-rata nilai hanya diperoleh dari satu hasil evaluasi; (2) sampel yang digunakan hanya satu kelas dari kelas parallel yaitu kelas C; (3) penerapan metode hanya diterapkan pada satu mata kuliah. Dengan demikian, berdasarkan keterbatasan tersebut dapat dijadikan saran bagi penelitian selanjutnya yaitu: (1) dapat menggunakan hasil evaluasi dari semua kuis yang dilaksanakan selama satu semester, di mana setengah semester dapat menggunakan metode IK, setengah semesternya lagi dapat menggunakan hybrid method; (2) penerapan metode dapat dilakukan pada materi yang sama namun di kelas statistik ekonomi dan bisnis yang berbeda seperti kelas A, B, dan D; (3) Penerapan metode dapat diimplementasikan pada mata kuliah lainnya.

\section{DAFTAR PUSTAKA}


Aurora, A., \& Effendi, H. (2019). Pengaruh Penggunaan Media Pembelajaran E-Learning Terhadap Motivasi Belajar Mahasiswa di Universitas Negeri Padang. Jurnal Teknik Elektro dan Vokasional, 11-16.

Cakrawati, L. M. (2017). Students' Perceptions on the Use of Online Learning Platforms in EFL Classroom. Englisih Language Teaching and Technology Journal (ELT-Tech Journal), 22-30.

Covid-19, S. T. (2020, November 18). covid19.go.id/beranda. Retrieved November 20, 2020, from covid19.go.id: www.covid19.go.id

Dimiyati \& Mujiono. (1999). Belajar dan Pembelajaran. PT. Rineka Cipta. Jakarta. 201

Dirjendikti. (2020). Panduan Penyelenggaraan Pembelajaran Semester Gasal 2020/2021 di Perguruan Tinggi Edisi 1, 22 Juni 2020. Indonesia.

Hartanto, W. (2016). Penggunaan E-Learning Sebagai Media Pembelajaran. Jurnal Pendidikan Ekonomi, 1-18.

Kemendikbud. (2020). Surat Edaran Nomor 15 Tahun 2020 tantang Pedoman Penyelenggaraan Belajar Dari Rumah dalam Masa Darurat Penyebaran Corona Virus Disease (Covid-19).

Keputusan Menteri Kesehatan, R. (2020). NOMOR HK.01.07/MENKES/328/2020 tentang Panduan Pencegahan dan Pengendalian Corona Virus Desease 2019 (Covid-19) di Tempat Kerja Perkantoran dan Industri dalam Mendukung Keberlangsungan Usaha pada Situasi Pandemi. Jakarta.

Kongchan, C. (2012). How a non-digital-native teacher makes use of Edmodo. ICT for Language Learning, 5th Edition. Florence: Pixel.

Manowong, S. (2016). Undergraduate students' perceptions of Edmodo as a supplementary learning tool in an EFL classroom. Silpakorn University Journal of Social Sciences, Humanities, and Arts, 137-161.

Mustakim. (2020). Efektivitas Pembelajaran Daring Menggunakan Media Online Selama Pandemi Covid-19 pada Mata Pelajaran Matematika. Al asma: Journal of Islamic Education, 1-12.

Nadziroh, F. (2017). Analisa Efektivitas Sistem Pembelajaran Berbasis E-Learning . Jurnal IImu Komputer dan Desain Komunikasi Visual, 1-14.

Rektor, S. (2020). Surat Edaran Rektor Nomor 1140/UN24/LL/2020 tentang Panduan Umum Penyelenggaraan Kegiatan Akademik di Universitas Palangka Raya dalam Tatanan Normal Baru (New Normal).

Suartini, N. K. (2020). Perspektif Mahasiswa dan Dosen Terhadap Efektivitas Pembelajaran Daring Selama Pandemi Covid-19. Cetta: Jurnaal Ilmu Pendidikan, 521-534.

Wahyuni, Y., \& Fauziah. (2015). Kajian Kesulitan Mahasiswa Terhadap Mata Kuliah Statistik Elementer. Lemma: Letters of Mathematics Educations, 76-82.

Widiyanto, A. M. (2013). Statistika Terapan: Konsep dan Aplikasi dalam Penelitian Bidang Pendidikan, Psikologi, Ilmu Sosial Lainnya. Jakarta: PT. Alex Media Komputindo. 